\title{
Stealing bivalves from common eiders: kleptoparasitism by glaucous gulls in spring
}

\author{
Øystein Varpe
}

Received: 17 March 2009 / Revised: 31 July 2009 / Accepted: 31 July 2009 / Published online: 13 September 2009

(C) The Author(s) 2009. This article is published with open access at Springerlink.com

\begin{abstract}
Here I report on glaucous gulls (Larus hyperboreus), an opportunistic, generalist predator, stealing bivalves from a diving duck, the common eider (Somateria mollissima). The study took place in spring, the pre-breeding period of the common eider, in an Arctic fjord (Adventfjorden) at western Spitsbergen, Svalbard. Eiders were abundant, their presence predictable, and they fed on large prey requiring surface handling —all factors facilitating food theft. Only adult glaucous gulls attended the eider flocks. The glaucous gulls brought stolen prey ashore. Amongst these the bivalve Mya neoovata (Myidae) was common. The probability that an eider flock was attended by glaucous gulls declined as the season progressed and increased with the foraging activity of the eiders. Eider flock size and the degree of aggregation within flocks were poor predictors of gull presence. However, eider flocks attended by a single gull were smaller than flocks attended by more than one gull. Common eiders are capital breeders which build up large energy reserves prior to breeding. Kleptoparasitism, therefore, may have a negative impact on eider energy acquisition in early spring. For the glaucous gull, kleptoparasitism may be important as few other food sources are available this time of the season.
\end{abstract}

Keywords Benthos ecology · Phenology $\cdot$ Predation · Seabirds $\cdot$ Sea ice $\cdot$ Trophic interactions

Electronic supplementary material The online version of this article (doi:10.1007/s00300-009-0712-4) contains supplementary material.

\section{$\emptyset$. Varpe $(\bowtie)$}

University Centre in Svalbard, PB 156,

9171 Longyearbyen, Norway

e-mail: oystein.varpe@unis.no

\section{Introduction}

Kleptoparasitism, stealing food captured by others, is common in many groups of animals, particularly in birds (Brockmann and Barnard 1979; Morand-Ferron et al. 2007). This behaviour also referred to as food theft, piracy, robbing or stealing, can be more profitable than capturing the same or other prey directly. Large birds or birds with high cognitive capabilities have been suggested to evolve kleptoparasitism, and ecological conditions related to the evolution of kleptoparasitism include an open habitat, large food items, and a social foraging environment (reviewed by Brockmann and Barnard 1979; Morand-Ferron et al. 2007).

Amongst avian groups, seabirds have a high proportion of kleptoparasites (Brockmann and Barnard 1979; Furness 1987). Some are specialised, such as some skuas and frigatebirds, relying on piracy for most or all of their energy acquisition, but most use kleptoparasitism opportunistically, including many gulls and terns. Opportunistic, or facultative, kleptoparasites typically have a range of foraging modes, with food theft being context-dependent, for instance related to periods of low availability of alternate food sources (Brockmann and Barnard 1979; Furness 1987; Triplet et al. 1999). Also within species, some individuals may be found to specialise as kleptoparasites, with higher fitness for kleptoparasitic compared to non-kleptoparasitic birds (Shealer et al. 2005).

Optimal foraging theory predicts that the foraging mode maximising net energy intake should be chosen (Stephens and Krebs 1986). Kleptoparasitism should therefore be abandoned if other food sources allow higher intake. The extent of kleptoparasitism may consequently serve as an indicator of the availability of alternative food sources. Furthermore, optimal foraging theory predicts 
that kleptoparasites should position themselves amongst hosts so that the rate of energy intake is maximised (Thompson 1986).

Here I report from a marine Arctic ecosystem where glaucous gulls (Larus hyperboreus) stole bivalves from common eiders (Somateria mollissima) in spring, a time when the common eiders prepare for breeding by intense foraging and energy storage (Parker and Holm 1990). Both species breed near the study location and are seasonal migrants, arriving in spring. The main objective of the study was to document this kleptoparasitic interaction, and specifically study how kleptoparasitism relates to time of the season and characteristics of the eider flocks. I expected eider flocks consisting of many, aggregated and actively foraging eiders to be most profitable for kleptoparasitising gulls.

\section{Materials and methods}

\section{Observations}

Observations were made in spring 2008 in Adventfjorden, part of the larger Isfjorden, near Longyearbyen $\left(78^{\circ} 13^{\prime} \mathrm{N}\right.$, $\left.15^{\circ} 38^{\prime} \mathrm{E}\right)$, Svalbard. In late April I observed glaucous gulls associated with rafts of feeding eiders trying to steal their food. Following these initial observations, systematic fieldwork was conducted (14 field days in the period 30 April to 9 June). The study ended when the eiders went ashore to breed. Two eider flocks consisting solely of king eiders (Somateria spectabilis) were omitted from the analyses. In the remaining 62 flocks, king eiders were present in 20, usually forming a small part, and in four cases forming more than half of the flock.

I observed from the shores and piers along the $\sim 5 \mathrm{~km}$ of road from Longyearbyen to Vestpynten. Eiders typically foraged $\sim 10-100 \mathrm{~m}$ from shore at depths of $\sim 5-20 \mathrm{~m}$. Flocks were usually observed from a car and my presence during the brief observation spells did not seem to influence the birds' behaviour. The glaucous gull was the only species attending eider flocks. Eider flocks were included in the study independently of whether they had associated gulls or not. Gulls on the water close to or within an eider flock were regarded as attending the flock and as potential kleptoparasites. Each flock was observed for the time needed to obtain the variables described below $(\sim 10$ $15 \mathrm{~min})$. This did not allow me to estimate attack and success rates.

\section{Variables and statistical analyses}

Each eider flock was described by: (1) its number of eiders, (2) their foraging intensity, (3) their degree of aggregation and (4) the number of attending gulls. As a proxy for foraging intensity I characterised the amount of diving by the members of a flock, using three levels: $0=$ no diving, 1 = some diving, 2 = regular diving. Three levels of aggregation were used: (1) low aggregation, a loose association of eiders but still forming a group of birds; (2) medium aggregation, a well defined flock with distances between birds of up to $\sim 15 \mathrm{~m}$; and (3) high aggregation, flocks with birds less than $\sim 5 \mathrm{~m}$ apart, and sometimes almost no water between them.

Presence or absence of gulls in the eider flocks were used as a proxy for kleptoparasitism. Generalised linear models (GLM) with a binary response variable $(0=$ gull absent, 1 =gull present), a logit link function, and a binomial distribution, were used to model the probability of kleptoparasitism. I included day of year and the three flock characteristics as explanatory variables. Interactions between the explanatory variables may be biologically realistic, but were not included due to the small dataset. The small sample Akaike's Information Criterion (AICc) was used to evaluate candidate models (Burnham and Anderson 2002). I report intercept $\alpha$ and slope $\beta$ for some of the candidate models, with $95 \%$ confidence limits (CL). Statistical analyses were performed using $\mathrm{R}$ (R Development Core Team 2007).

\section{Study species}

The biology of the glaucous gull and the common eider in Svalbard has been reviewed (Anker-Nilssen et al. 2000; Løvenskiold 1964; Mehlum 1991). Glaucous gulls return to Svalbard in March-April, with egg laying in late Mayearly June. The glaucous gull is the main avian predator in Svalbard, preying heavily on eggs and offspring of other birds, such as common eiders, kittiwakes (Rissa tridactyla) and common guillemots (Uria aalge), but also taking adults of some species, such as the little auk (Alle alle). The glaucous gull can also take newborn ringed seal (Phoca hispida) pups (Lydersen and Smith 1989). Carcasses, remains at garbage dumps, offal from fishing boats, fish and various large plankton and littoral species are also amongst the food reported for this opportunistic predator and scavenger.

The common eider is the most numerous duck breeding in Svalbard. Egg laying takes place when the tundra is free from snow, and on small islands after the sea ice connection with the mainland has been broken, thus preventing access by the Arctic fox (Alopex lagopus). The common eider migrate south during winter, but some birds are observed over-wintering on the west coast of Spitsbergen (G Bangjord pers. com.). Common eiders typically forage in flocks and generally dive to depths less than $10 \mathrm{~m}$ (Bustnes and Lønne 1997). The few studies from Svalbard report a mainly benthic diet (Dahl et al. 2003) consisting of 
molluscs, including bivalves, but also crustaceans such as Gammarus spp.

\section{Results}

Glaucous gulls were present in 20 of 62 eider flocks (Figs. 1, 2a; Table 1) and only adult gulls were seen. During my short observation spells, gulls tried to steal food from common eiders in six of the flocks, sometimes successfully (photos in Fig. A1, electronic supplementary material). One of these six flocks contained king eiders, but no attempt to steal from them was observed.

Gulls attending eider flocks lay on the water, watched for surfacing eiders, and flew towards eiders that surfaced with food. The eider responded to an attack by diving, usually returning to the surface without the prey. Gulls brought stolen bivalves ashore. On one occasion a gull dropped the bivalve from some height, presumably with the intention to break it. I found remains of some 40 individual bivalves at a site to which I once observed a gull bring its prey, a newly made pier (photos in Fig. A2, electronic supplementary material). Presumably, this location was used repeatedly by glaucous gulls. A subsample of these bivalves consisted of large specimens ( $\sim 6 \mathrm{~cm}$ in length) of Mya neoovata (GH Petersen, pers. com.) and Serripes groenlandicus (photos in Fig. A2, electronic supplementary material).

The size of eider flocks varied (mean $=30, \mathrm{SD}=33$, range [3-208]; Figs. 1, 2b). Flock size ( $\log _{10}$ transformed) declined as the spring progressed (linear regression: $R^{2}=0.15, \quad \alpha=2.9 \quad[2.0, \quad 4.3], \quad \beta=-0.014 \quad[-0.022$, $-0.006]$ ). Amongst flocks attended by gulls, those attended by more than one gull were larger than flocks with a single gull (mean $\log _{10}$ flock size of 1.8 and 1.2, respectively, $95 \%$ CL for difference in means: [0.2, 0.9]). No difference in mean flock size was suggested for the three levels of diving activity or for aggregation.
About half the flocks contained diving eiders (Fig. 2c). Most flocks showed a medium level of aggregation (Fig. 2d). Diving activity declined with increasing level of aggregation (Kruskal-Wallis test comparing medians: $K=9.2, P<0.05$, mean diving activity: $1.5,0.9$, and 0.3 for aggregation level 1,2, and 3, respectively).

Model selection suggested day of year and foraging activity (diving) as predictors of the probability of gull attendance, the proxy used for kleptoparasitism (Table 2). The probability of gull presence declined with season (Fig. 3) and increased with diving activity. Specifically, flocks with regular diving were more likely to have gulls present than flocks with the two lower diving levels (parameters in Fig. 3). For models with one explanatory variable present at the time, day of year provide a suitable model, whereas level of aggregation performed particularly poorly (Table 2).

\section{Discussion}

It may be surprising that the large glaucous gulls, usually efficient predators and scavengers, find the stealing of bivalves rewarding. However, the social foraging by eiders, the open habitat offering good visibility, the predictable occurrence of eiders both in time and space, and the eider's handling of prey at the surface are all factors that may make energy intake through kleptoparasitism profitable (Brockmann and Barnard 1979). Female common eiders are capital breeders that fast during the incubation period and lose $\sim 45 \%$ of their body mass from prelaying to hatching (Parker and Holm 1990). Hence, they rely on large energy reserves built up during winter and prior to breeding through active foraging on presumably high quality prey, the latter potentially increasing the profitability of kleptoparasitism. Additionally, because the eider's handling time is likely to increase with prey size (Guillemette et al. 1992),
Fig. 1 The number of eiders per flock against time during spring $(1$ May = 121), and whether gulls were attending an eider flock or not. The size of open circles indicates the number of gulls per flock, ranging from 1 to 10 (see Fig. 2a)

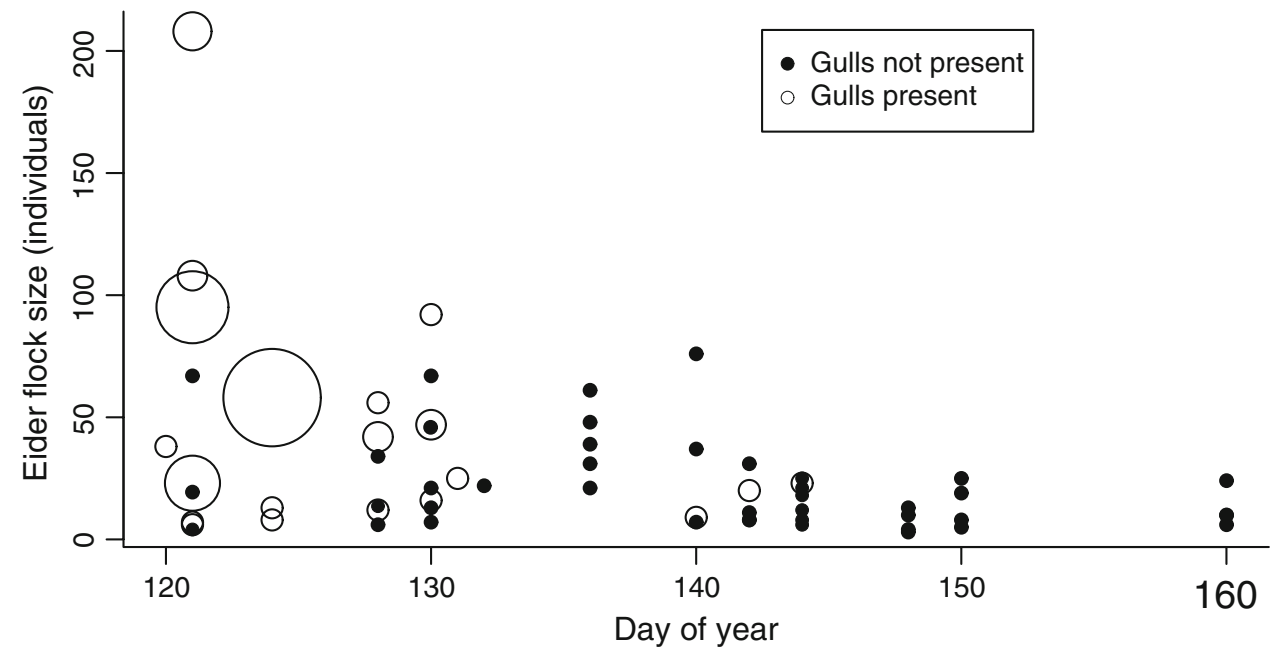



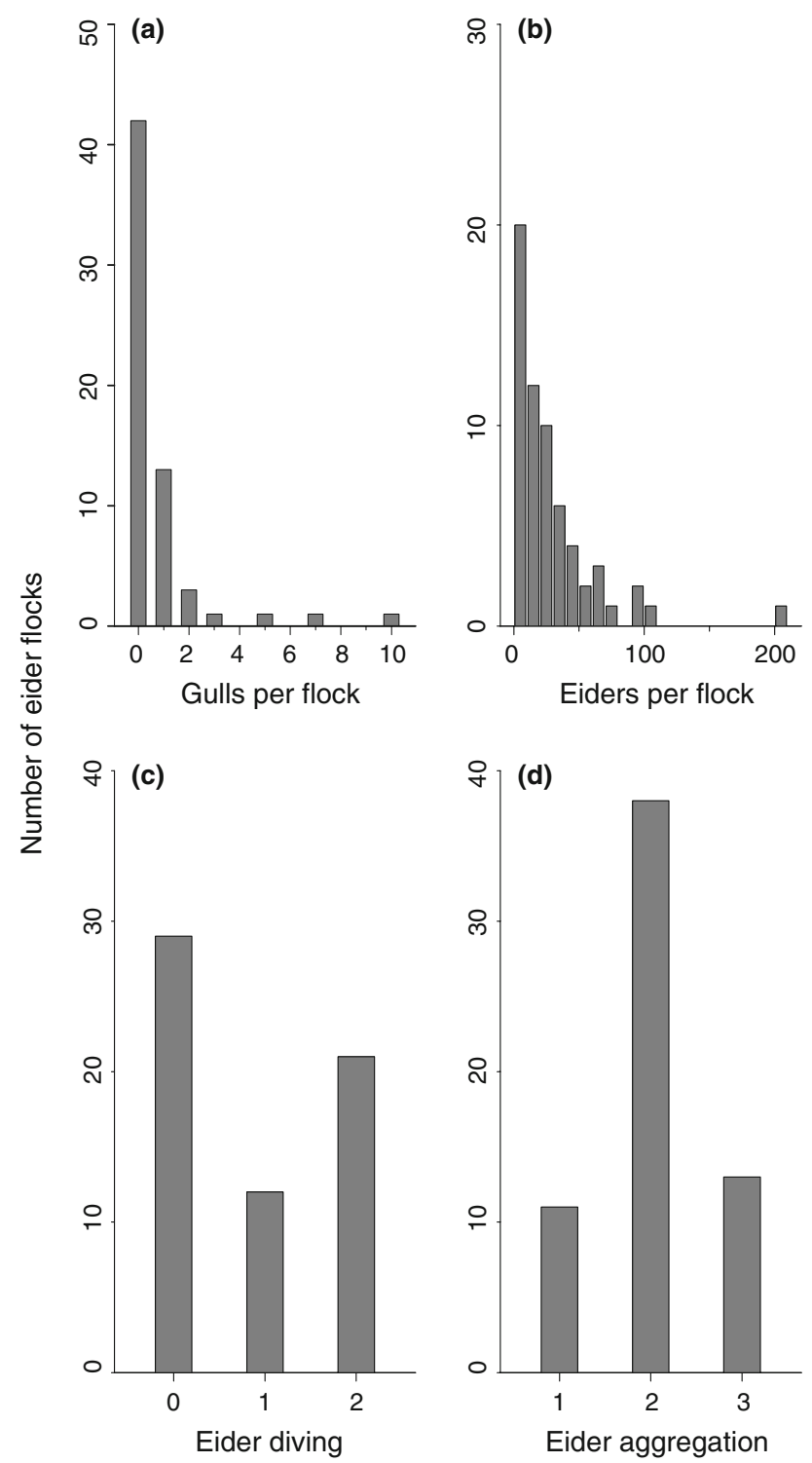

Fig. 2 Frequency distributions of: a number of glaucous gulls per eider flock; $\mathbf{b}$ number of eiders per flock, in bins of 10 birds; $\mathbf{c}$ diving intensity of an eider flock (no diving $=0$, some diving $=1$, regular diving =2); and d eider aggregation within a flock (low $=1$, medium $=2$, high $=3$ )

Table 1 Number of eider flocks with and without glaucous gulls, mean flock size (number of individuals per flock with standard error), and the number of flocks in the different diving (no diving $=0$, some diving $=1$, regular diving $=2$ ) and aggregation (low $=1$, medium $=2$, high = 3) categories

\begin{tabular}{|c|c|c|c|c|c|c|c|c|}
\hline \multirow{2}{*}{$\begin{array}{l}\text { Glaucous } \\
\text { gull } \\
\text { present }\end{array}$} & \multirow{2}{*}{$\begin{array}{l}\text { Number } \\
\text { of eider } \\
\text { flocks }\end{array}$} & \multirow{2}{*}{$\begin{array}{l}\text { Mean } \\
\text { eider } \\
\text { number }\end{array}$} & \multicolumn{3}{|c|}{ Eider diving } & \multicolumn{3}{|c|}{ Eider aggregation } \\
\hline & & & 0 & 1 & 2 & 1 & 2 & 3 \\
\hline Yes & 20 & 45 & 4 & 3 & 13 & & 12 & 4 \\
\hline No & 42 & $22(3)$ & 25 & 9 & 8 & t & 26 & 9 \\
\hline
\end{tabular}

the pirate will also get at the largest, most valuable prey. Indeed, the Mya neoovata individuals brought ashore by gulls were large specimens (GH Petersen, pers. com.).

Kleptoparasitism of common eiders by glaucous gulls has to my knowledge not been reported from Svalbard, but it has been observed in Iceland (Ingolfsson 1969) and Scotland (Prys-Jones 1973). Glaucous gulls may also steal from other seabirds (Brockmann and Barnard 1979; Stempniewicz 1983), but of ducks, only kleptoparasitism of the common eider has been reported. Also other gull species steal from common eiders (references in Brockmann and Barnard 1979), commonly so when wintering eiders forage in large flocks (e.g. Källander 2006).

The behaviour of glaucous gulls during attacks and prey capture was mostly similar to that reported by Ingolfsson (1969) and Prys-Jones (1973). However, they did not report that the gulls brought stolen prey ashore. If it is important to handle the prey ashore, or to drop it to break it open, this may constrain kleptoparasitism, making it less common when hosts dive far from shore or in areas lacking suitable dropping locations.

\section{Seasonality in kleptoparasitism}

As the season progressed, and the eiders' egg laying season approached, gulls were more seldom attending eider flocks. There may be at least two explanations for this. First, opportunistic kleptoparasites often steal food during shortages of other food items (Brockmann and Barnard 1979). Consequently, alternative prey may have been scarce early in the study, whereas later in spring colony breeding seabirds start egg laying, potentially offering more profitable foraging opportunities. The diet of glaucous gulls in their pre-breeding period is poorly known, but at the time glaucous gulls arrive in spring, seasonal food sources, such as pups of the ringed seal (Lydersen and Smith 1989) and carcasses of Svalbard reindeer (Rangifer tarandus) may be important. However, these sources most likely play a role prior to the period studied here. Second, the observed seasonal decrease in gull attendance may be explained by changes in eider behaviour. During the latter part of the study, flocks became smaller, but still containing many females, and were located mostly in the inner part of Adventfjorden.

\section{Kleptoparasitism and eider flock characteristics}

Gulls were more likely to associate with flocks of foraging eiders than with non-diving flocks, in line with predictions from optimal foraging theory. Similar regulation of kleptoparasitic activity in relation to prey availability include jackdaws (Corvus monedula) mainly monitoring kleptoparasitic opportunities when common guillemots are likely to 
Table 2 Model selection for the analyses of gull presence in eider flocks

\begin{tabular}{|c|c|c|c|c|c|c|c|c|}
\hline$i$ & $\begin{array}{l}\text { Day } \\
\text { of year }\end{array}$ & $\begin{array}{l}\text { Flock } \\
\text { size }\end{array}$ & Diving & Aggregation & $\mathrm{K}$ & $\begin{array}{l}\text { Res } \\
\text { Dev }\end{array}$ & $\mathrm{AICc}$ & $\Delta$ \\
\hline 16 & $x$ & $x$ & $x$ & $x$ & 7 & 44.2 & 61.0 & 3 \\
\hline 15 & & $x$ & $x$ & $x$ & 6 & 56.3 & 70.4 & 13 \\
\hline 14 & $x$ & & $\times$ & $x$ & 6 & 45.3 & 59.4 & 2 \\
\hline 13 & $x$ & $x$ & & $x$ & 5 & 54.7 & 66.2 & \\
\hline 12 & $x$ & $x$ & $x$ & & 5 & 46.7 & 58.2 & \\
\hline 11 & & & $x$ & $x$ & 5 & 62.8 & 74.3 & 17 \\
\hline 10 & & $x$ & & $x$ & 4 & 71.1 & 80.2 & 23 \\
\hline 9 & & $x$ & $x$ & & 4 & 57.9 & 67.0 & \\
\hline 8 & $x$ & & & $x$ & 4 & 55.6 & 64.6 & \\
\hline 7 & $x$ & & $x$ & & 4 & 48.1 & 57.2 & 0 \\
\hline 6 & $x$ & $x$ & & & 3 & 55.2 & 61.9 & 4 \\
\hline 5 & & & & $x$ & 3 & 77.9 & 84.6 & 27 \\
\hline 4 & & & $x$ & & 3 & 64.7 & 71.4 & 14 \\
\hline 3 & & $x$ & & & 2 & 71.2 & 75.6 & 18 \\
\hline 2 & $x$ & & & & 2 & 56.2 & 60.6 & 3 \\
\hline 1 & & & & & 1 & 78.0 & 80.2 & 23 \\
\hline
\end{tabular}

Relative evidence for each candidate model $i$ is based on differences in AICc. Explanatory variables included in each candidate model are marked with an $\times$. $\mathrm{K}$ is the number of parameters estimated for each model and Res Dev is residual deviance. The model in bold had the lowest AICc value. $\Delta$ is the difference in AICc between this and other candidate models. Analyses were based on 62 flocks

return to the colony with fish (Birkhead 1974) and Arctic skuas (Stercorarius parasiticus) performing more chases when the number of fish-carrying auks is high (Caldow and Furness 2001).
Similarly, large eider flocks should be more profitable for glaucous gulls (Dunn 1973), but in the present study flock size was a poor predictor of gull attendance. However, there were fewer eiders in flocks with one gull than in flocks with several gulls, pointing towards an ideal free distribution of kleptoparasites. In contrast, Ingolfsson (1969) and Prys-Jones (1973) reported that single gulls defended rafts of eiders against other gulls. I did not observe such defence.

Aggregated hosts may imply good conditions for kleptoparasitism, for instance because of short flight distance to hosts (Thompson 1986), but in the present study eider aggregation was not suggested to predict gull presence. In fact, the foraging activity of eiders declined with degree of aggregation, counteracting the potential benefit of many hosts on a small area. Possibly, resting eiders may form these dense flocks.

Estimates of attack rates and capture success are needed to improve our understanding of this kleptoparasitic interaction. Future studies should also study if certain eiders are targeted hosts (cf. Ridley and Child 2009) and how eiders' respond to kleptoparasitism. Expected behavioural responses include more synchronous diving (Schenkeveld and Ydenberg 1985) and capture of prey requiring shorter handling time (Barnard et al. 1982).

Mya and the diet of common eiders

The Mya individuals in the present study were Mya neoovata (identified by GH Petersen), a species recently distinguished from Mya truncata (Petersen 1999). Almost all reports of Mya species in Svalbard are of Mya truncata

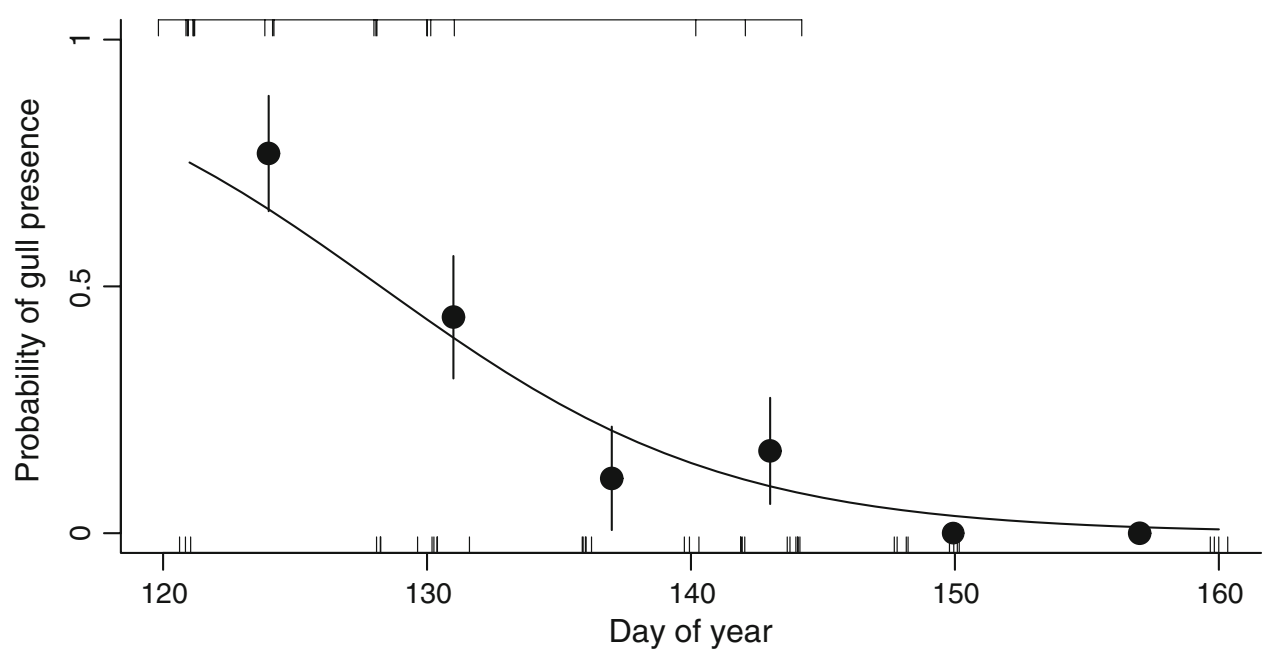

Fig. 3 The probability of kleptoparasitism as predicted by time during spring $(1$ May $=121)$, with presence of gulls in eider flocks as proxy for kleptoparasitism. Days with eider flock observations marked on the upper (gulls present) and lower (gulls absent) $x$-axis. The curve is predicted from candidate model 2 (Table 2), parameters and confidence limits: $\alpha=19.6[10.0,31.2], \beta=-0.15[-0.24,-0.08]$. To compare the fit of the model, empirical probabilities (black circles) with standard errors are shown for six time intervals. If including the three level variable for diving activity, candidate model $7, \beta=-0.16[-0.26$, $-0.07]$, whereas the intercept $\alpha=19.6[8.2,32.8], 20.0[7.0,35.8]$ and $21.3[8.8,36.8]$, for diving level 0,1 and 2 , respectively 
(Gulliksen et al. 1999; Palerud et al. 2004; WlodarskaKowalczuk 2007), which unlike Mya neoovata is truncated. A few observations of the non-truncated Mya arenaria have been reported from Svalbard, individuals possibly fitting Petersen's (1999) description of Mya neoovata (see also Odhner 1915). The species of Mya are erected on digging behaviour, habitat and shell morphology. Further studies are needed to understand the ecological basis for this variation. Sampling burrowing bivalves is difficult, and may leave us with a biased view of their distribution. Using the diet of predators may help us achieve a more representative picture.

The use of eider diet to study bivalve distribution may have further applications. There have been recent signs of reappearance of the blue mussel Mytilus edulis in Svalbard waters (Berge et al. 2005). Blue mussels are the dominant prey of common eiders at lower latitudes (Bustnes and Erikstad 1988) and, if the blue mussel gets established, should appear in the diet of common eiders at an early stage, and potentially be stolen by gulls. Ingolfsson (1969) and Prys-Jones (1973) assumed that the blue mussel was the main prey that glaucous gulls robbed from common eiders.

Based on the bivalves stolen from the eiders and brought ashore by the glaucous gulls, Mya neoovata seemed to be a frequent prey of the common eider. Bivalves are abundant in the diet of common eiders (Anker-Nilssen et al. 2000), and the similar Mya eideri was the dominant prey of common eiders wintering in western Greenland (Merkel et al. 2007). There are few studies of eider diet in Svalbard waters, and to my knowledge no studies from the eiders' pre-breeding period. This is unfortunate given the close links between breeding success and pre-breeding foraging expected for the capital breeding common eider (Hanssen et al. 2005; Parker and Holm 1990). The fjords of western Spitsbergen are often ice covered in spring, preventing eiders from foraging, but sea ice dynamics are changing at least on the larger Arctic scale (Lindsay et al. 2009). Less ice in spring would make foraging habitats near the breeding locations available to the common eider. An increased foraging area during summer is similarly expected for walrus (Odobenus rosmarus) at Greenland, another Arctic predator that feeds on bivalves (Born et al. 2003). Hence, high latitudes, such as the coasts of Svalbard, may become more attractive pre-breeding foraging areas for the common eider-but with kleptoparasitism by glaucous gulls as a potential stressor.

Acknowledgments I thank B. J. Bårdsen and P. E. Renaud for comments on an earlier version of this manuscript, G. Bangjord, E. Johansson-Karlsson and M. Lagerborg for discussions on kleptoparasitism, J. Berge, S. R. Birkely, B. Gulliksen, O. J. Lønne, G. H. Petersen, and J. A. Sneli for discussions on benthos ecology, and G. H. Petersen for identification of Mya neoovata. J. M. Weslawski and two anonymous reviewers also provided valuable comments. The study was made possible through grants from ConocoPhillips and Svalbard's Environmental Protection Fund.

Open Access This article is distributed under the terms of the Creative Commons Attribution Noncommercial License which permits any noncommercial use, distribution, and reproduction in any medium, provided the original author(s) and source are credited.

\section{References}

Anker-Nilssen T, Bakken V, Strøm H, Golovkin AN, Bianki VV, Tatarinkova IP (2000) The status of marine birds breeding in the Barents Sea area. Norsk Polarinstitutt Rapportserie 113. Nor Polar Inst, Troms $\varnothing$

Barnard CJ, Thompson DBA, Stephens H (1982) Time budgets, feeding efficiency and flock dynamics in mixed species flocks of lapwings, golden plovers and gulls. Behaviour 80:44-69

Berge J, Johnsen G, Nilsen F, Gulliksen B, Slagstad D (2005) Ocean temperature oscillations enable reappearance of blue mussels Mytilus edulis in Svalbard after a 1000 year absence. Mar Ecol Prog Ser 303:167-175

Birkhead TR (1974) Utilization of guillemot Uria aalge colonies by jackdaws Corvus monedula. Ornis Scand 5:71-81

Born EW, Rysgaard S, Ehlme G, Sejr M, Acquarone M, Levermann N (2003) Underwater observations of foraging free-living Atlantic walruses (Odobenus rosmarus rosmarus) and estimates of their food consumption. Polar Biol 26:348-357

Brockmann HJ, Barnard CJ (1979) Kleptoparasitism in birds. Anim Behav 27:487-514

Burnham KP, Anderson DR (2002) Model selection and multimodel inference: a practical information-theoretic approach, vol 2 . Springer, New York

Bustnes JO, Erikstad KE (1988) The diets of sympatric wintering populations of common eider Sommateria mollissima and king eider S. spectabilis in northern Norway. Ornis Fenn 65:163-167

Bustnes JO, Lønne OJ (1997) Habitat partitioning among sympatric wintering Common Eiders Somateria mollissima and King Eiders Somateria spectabilis. Ibis 139:549-554

Caldow RWG, Furness RW (2001) Does Holling's disc equation explain the functional response of a kleptoparasite? J Anim Ecol 70:650-662

Dahl TM, Falk-Petersen S, Gabrielsen GW, Sargent JR, Hop H, Millar RM (2003) Lipids and stable isotopes in common eider, blacklegged kittiwake and northern fulmar: a trophic study from an Arctic fjord. Mar Ecol Prog Ser 256:257-269

Dunn EK (1973) Robbing behavior of roseate terns. Auk 90:641-651

Furness RW (1987) Kleptoparasitism in seabirds. In: Croxall JP (ed) Seabirds: feeding ecology and role in the marine ecosystem. Cambridge Univerity Press, Cambridge, pp 77-100

Guillemette M, Ydenberg RC, Himmelman JH (1992) The role of energy intake rate in prey and habitat selection of common eiders Somateria mollissima in winter: a risk-sensitive interpretation. J Anim Ecol 61:599-610

Gulliksen B, Palerud R, Brattegard T, Sneli JA (1999) Distribution of marine benthic macro-organisms at Svalbard (including Bear Island) and Jan Mayen. In: Research Report for DN. Directorate for Nature Management

Hanssen SA, Hasselquist D, Folstad I, Erikstad KE (2005) Cost of reproduction in a long-lived bird: incubation effort reduces immune function and future reproduction. Proc R Soc B 272:1039-1046

Ingolfsson A (1969) Behaviour of gulls robbing eiders. Bird Study $16: 45-52$

Källander H (2006) Interspecific kleptoparasitism by four species of gull Larus spp. in South Sweden. Ornis Svec 16:127-149 
Lindsay RW, Zhang J, Schweiger A, Steele M, Stern H (2009) Arctic sea ice retreat in 2007 follows thinning trend. J Climate 22:165176

Løvenskiold HL (1964) Avifauna Svalbardiensis. Norsk Polarinstitutt Skrifter 129

Lydersen C, Smith TG (1989) Avian predation on ringed seal Phoca hispida pups. Polar Biol 9:489-490

Mehlum F (1991) Eider studies in Svalbard. Norsk Polarinstitutt Skrifter 195

Merkel FR, Jamieson SE, Falk K, Mosbech A (2007) The diet of common eiders wintering in Nuuk, Southwest Greenland. Polar Biol $30: 227-234$

Morand-Ferron J, Sol D, Lefebvre L (2007) Food stealing in birds: brain or brawn? Anim Behav 74:1725-1734

Odhner N (1915) Die Molluskenfauna des Eisfjordes. K Sv Vet Akad Handl 54(1)

Palerud R, Gulliksen B, Brattegard T, Sneli JA, Vader V (2004) The marine macro-organisms in Svalbard waters. In: Prestrud $P$, Strøm H, Goldman HV (eds) A catalogue of the terrestrial and marine animals of Svalbard. Norsk Polarinstitutt Skrifter 201, Troms $\varnothing$, pp 5-56

Parker H, Holm H (1990) Patterns of nutrient and energy-expenditure in female common eiders nesting in the high Arctic. Auk 107:660-668

Petersen GH (1999) Five recent Mya species, including three new species and their fossil connections. Polar Biol 22:322-328
Prys-Jones OE (1973) Interactions between gulls and eiders in St. Andrews Bay, Fife. Bird Study 20:311-313

R Development Core Team (2007) R: a language and environment for statistical computing. R Foundation for Statistical Computing, Vienna, Austria

Ridley AR, Child MF (2009) Specific targeting of host individuals by a kleptoparasitic bird. Behav Ecol Sociobiol 63:1119-1126

Schenkeveld LE, Ydenberg RC (1985) Synchronous diving by surf scoter flocks. Can J Zool 63:2516-2519

Shealer DA, Spendelow JA, Hatfield JS, Nisbet ICT (2005) The adaptive significance of stealing in a marine bird and its relationship to parental quality. Behav Ecol 16:371-376

Stempniewicz L (1983) Glaucous gulls stealing spoil from parasitic jaegers. J Field Ornithol 54:331

Stephens DW, Krebs JR (1986) Foraging theory. Princeton University Press, Princeton

Thompson DBA (1986) The economics of kleptoparasitism: optimal foraging, host and prey selection by gulls. Anim Behav 34:11891205

Triplet P, Stillman RA, Goss-Custard JD (1999) Prey abundance and the strength of interference in a foraging shorebird. J Anim Ecol 68:254-265

Wlodarska-Kowalczuk M (2007) Molluscs in Kongsfjorden (Spitsbergen, Svalbard): a species list and patterns of distribution and diversity. Polar Res 26:48-63 